\title{
Importance of the (Amateur Photographer) Zaklama Archive in the Documentation of the Egyptian Heritage
}

\author{
'Mervat Guirguis Abdallah ${ }^{2}$ Francis Amin Mohareb ${ }^{3}$ Emil Henin \\ 1- Researcher, Collector, Curator of Exhibitions and Conservator in Photography - Faculty of Fine Art - \\ Alexandria. mervatfrans@gmail.com \\ 2- Researcher in Archeology - Honorary Italian Consul - Luxor. francamin2000@yahoo.com \\ 3- Head of Coptic Painting Conservation Department at Monasteries and Churches at Harat Zuweila, \\ Cairo. (Ministry of Tourism and Antiquities) omel2010@yahoo.com
}

\begin{abstract}
The value and importance of" old photographs" as personal memory \&in the field of scientific research is beyond doubt, it records many historical and social events, and brings history alive as memory and true witness of begone years. . However they are particularly important as a manner to sharing cultural heritage .

Egypt was a destination for photographers, whether Egyptians or foreigners. In this research, we will focus on one the "amateur photographers" who was interested in recording Egyptian antiquities, especially Islamic and Coptic antiquities.
\end{abstract}

His name is Shafyk Zaklama, about whom nothing has been written and through his archives, we have come to a brief summary of what he presented to us and to future generations concerning the Egyptian heritage.

Zaklama's archive represent great benefit in preserving the Egyptian photographic heritage ,from other part it represents a great importance in the field of restoration of monuments ,buildings and ornaments. 


\section{Introduction}

Photographs play an important role in everyone's life, they connect us to our past, It is considered as a unique documentary record in life, , environment, society, and the cultural product for a certain period of time.

the photographers were usually taking photoshoot of famous landmarks in big cities like Cairo and Alexandria etc. and in the country side, especially for commercial purposes. For Example the famous photographer G.Lekegian did not leave a trace of buildings unless he photographed in an artistic way

There are researchers who have practiced photography for study, research and documentation, such as the Islamic archaeologist Creswell and his student Hassan Abdel-Wahhab,and most of their photographs are published..

Zaklama, photographed many Coptic monasteries ,churches, some mosques and buildings , and the still standing monuments in Egypt between the years 1910 to 1950. 


\section{- The usefulness of photographs in the documentation and restoration work of archaeological buildings}

The old photographs are of great importance in preserving and restoring the cultural heritage.

Photographic Documents are areal bond in the relationship between past \& present.

Photographs contain a wealth of information which may be used effectively in historical research. Visual images may be used as evidence, for illustration, comparison, contrast, and for analytical purposes.

Cairo, which is distinguished from other ancient Egyptian and global cities, has been founded more than ten centuries ago, it became the scene of historical, political and artistic events over the centuries, like other cities as Alexandria, Port Said, Luxor, Aswan etc. Today They show great difference The photographs reveal how the city of Cairo lost, over hundreds of years, many of its historical palaces, ancient mosques, number of its buildings, especially houses and public buildings. 
Nothing remains but ,historical descriptions, drawings and photographs that help to know their ancient form and aspects.. For example, 20 years ago, the (Musafir khana Palace ) was devoured by fire [1], it's a historical building where Khedive Ismail was born, The Ministry of Culture announced that old pictures will be used to rebuild it, which never happened yet, unfortunately.

Parts of many pulpits have been stolen .. Earthquakes caused the demolition of a complete or partially buildings.

It's is possible to rely on old photographs in their restoration, reconstruction and the analytical and historical studies.

The expansions carried out by the Khedive Ismail required the establishment of modern Cairo by expanding the main streets. The old early photographs and paintings remain as the only witness of those buildings ,like the Azbek mosque, from his name the Azbakeya quarter derives it's name.[2]

Comparing the old photos of the villa of the French Consulate, (Figure 1,A.B.C) [3] which is called "Villa of the count Saint-Maurice", which was demolished to build the famous lmobilia building in 1937( the French embassy transferred many elements of the building, such as doors, windows, mashrabiyas, and marble units that were on the floor of the villa to their new embassy in Giza) [4] we could get a real description of the original building through the old photographs. 


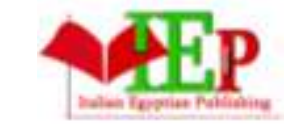

ISSN: 2785-9622

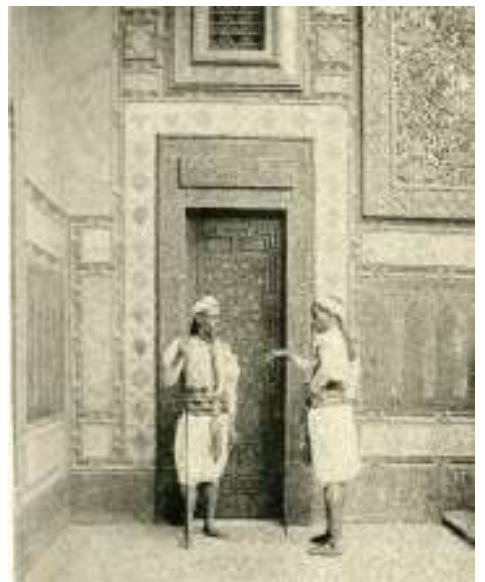

A

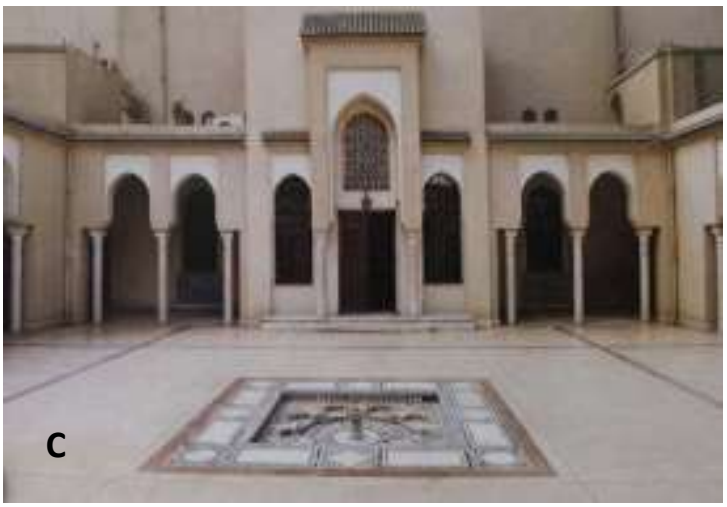

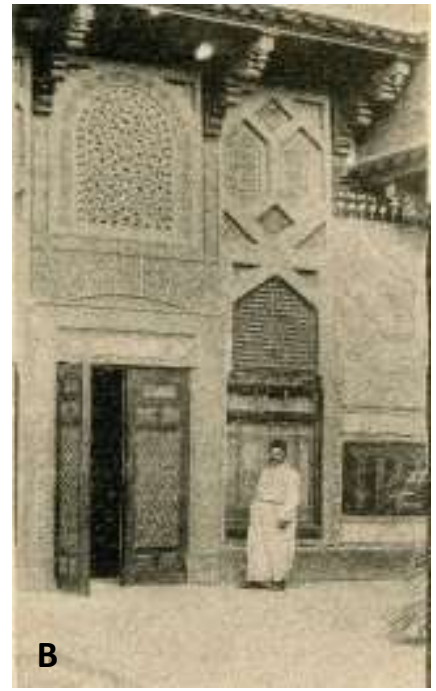

( Figure 1,A.B.C) The doors of the old Villa in it's new palace in the French embassy at giza

After the second war, many temples were used as a quarries and disappeared , such as Cleopatra bath in Aswan(Figure 2), the north temple of Esna, and the Temple of Armant [5] , which was photographed by many photographers, starting from Maxime du Camp, Francis Frith and others, And We suggested to use Francis Frith's photos, which are of high quality.

Christophe Thier, who was then the director of the Centre Franco-Egyptien at Karnak following our suggestions used those photographs forin publuishing the lost texts of the essential parts of this temple. 


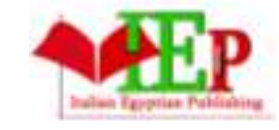

ISSN: $2785-9622$

\section{Examples of lost heritage}

\section{As, Houses-Temples - Churches - transferred buildings.}

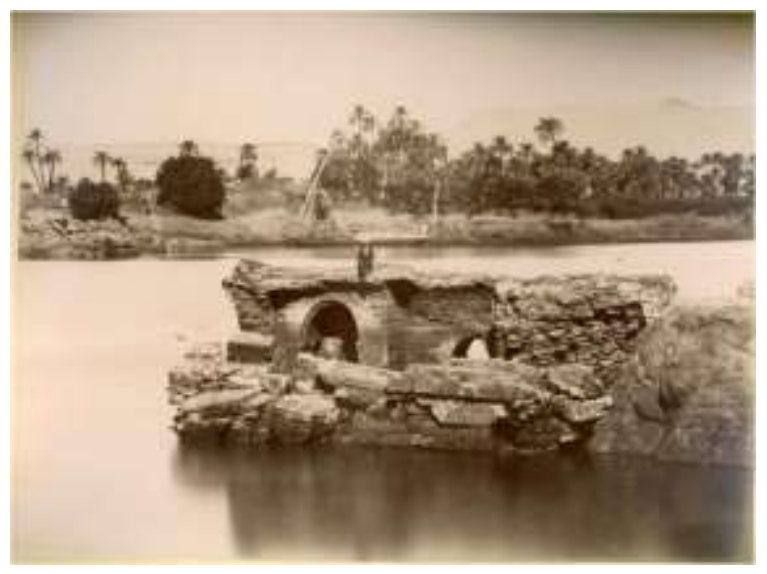

( Figure 2 )Cleopatra bath in Aswan, which does not exist now. Photo by Francis Frith, 1858)privet collection

Philae is an island on the Nile, ( Figure 3 ) forming part of old Nubia in Upper Egypt. which is submerged totally by the water of the old dam .

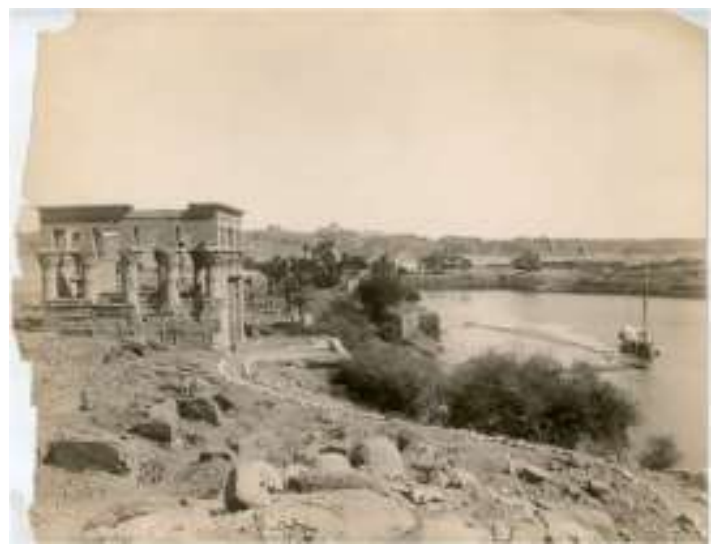

( Figure 3) Philae is an island on the Nile, which does not exist now (privet collection ) 
Photography was further revolutionized by the introduction of more accessible and more portable materials.. most of the photographers of the nineteenth century were not bound to document monuments in a systematic method, they w recorded their voyages and experimented it with simple cameras.

To reimagine the scenes of the birth house of Cleopatra VII at Armant, we must use the albums of Frith ( Figure 4), as the small temple was torn down

to build a sugar factory shortly after Frith's visit In $1857 \mathrm{He}$ is also one of the first photographers in Nubia.[5]

Photographers made always part of archeological missions ,and epigraphic surveys. . The photographs represent what Frith termed as "essential truthfulness,"

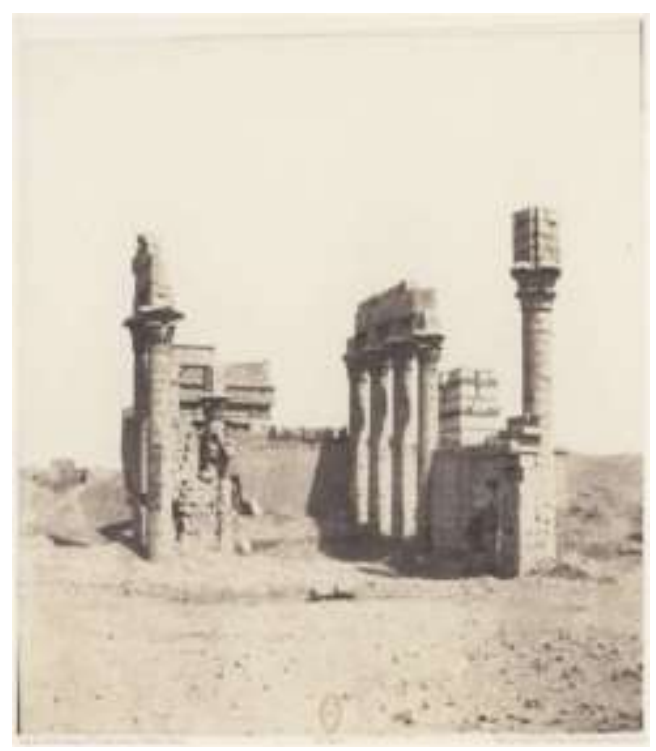

( Figure 4) General View of the Ruins - Cleopatra's Temple at Armant and Mammisi by Félix Teynard wikimedia.[6] 


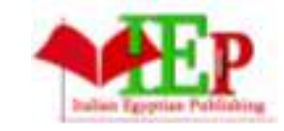

ISSN: 2785-9622
INTERNATIONAL JOURNAL OF

MULTIDISCIPLINARY STUDIES IN HERITAGE

RESEARCH

VOLUME 4, ISSUE 1, 2021, $260-283$.

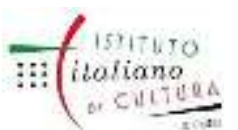

www.egyptfuture.org/ojs/

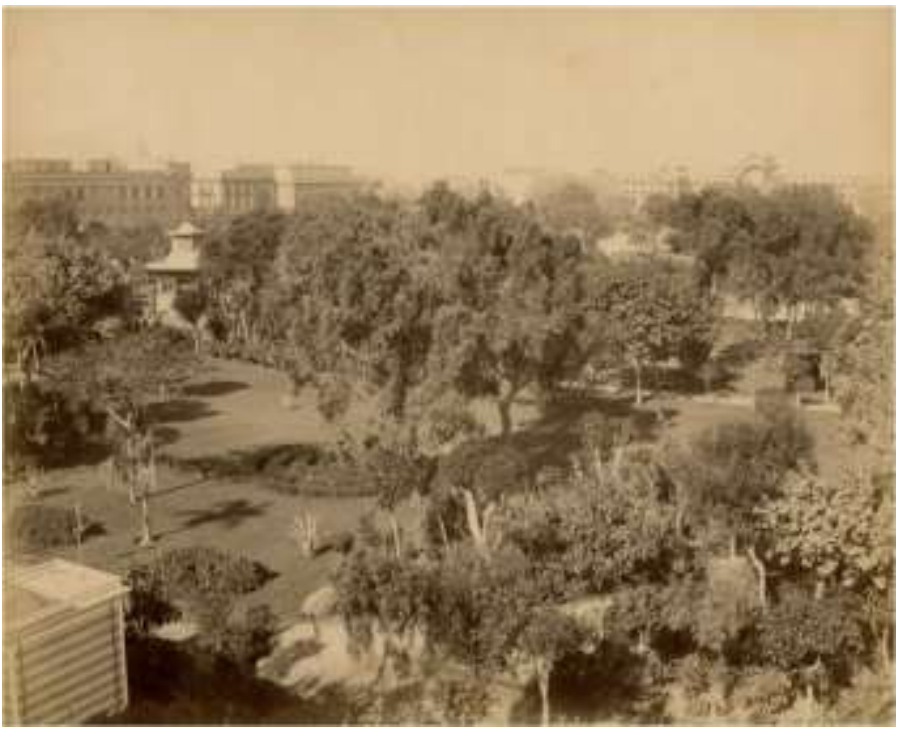

(Figure 5) The Azbakeya Garden which does not exist now .-

Fiorillo1880 (privet collection)

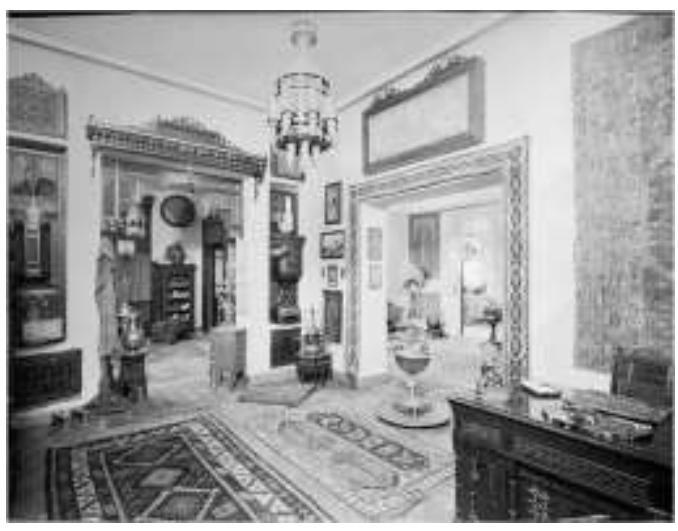

( Figure 6) Shepheard's Hotel was one of the most celebratedhotels in the world from the middle of the 19th century until its total destruction in 1952 during the Cairo fire [7]

Photo by Kerop , privet collection. 


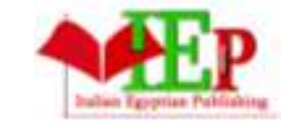

ISSN: 2785-9622

\section{INTERNATIONAL JOURNAL OF \\ MULTIDISCIPLINARY STUDIES IN HERITAGE \\ RESEARCH}

VOLUME 4, ISSUE 1, 2021, 260 - 283.

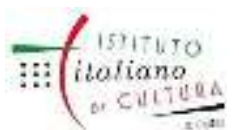

www.egyptfuture.org/ojs/

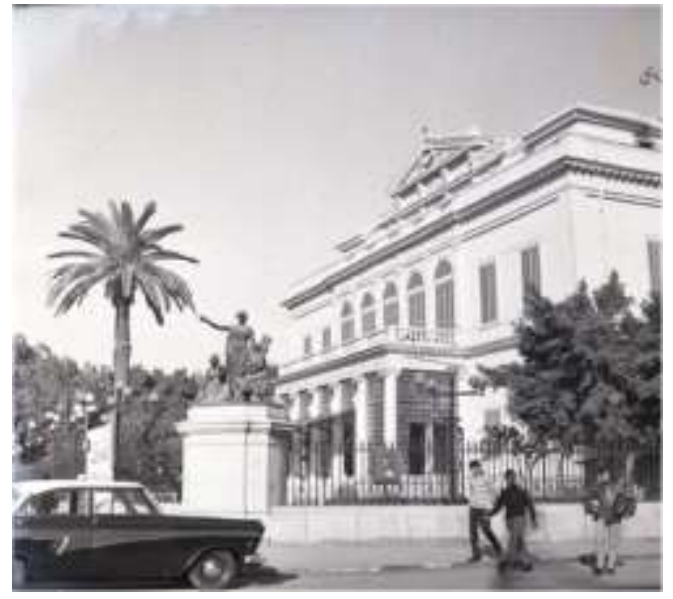

(Figure 7) The Royal Opera House in Cairo, Egypt, the oldest opera house in all Africa. It was inaugurated on 1 November 1869 and burned down on 28 October 1971 [8]. photo by Kamal Rashid 1955 privet collection.

Examples of buildings that have had some change over time ( figure 8,A.B )(Figure 9,A.B)

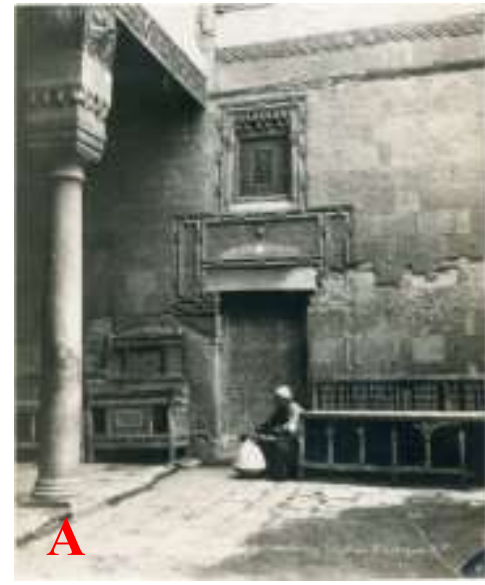

(Figure 8,A.B) Al-Arousi's house, which does not exist now .( privet collection)
The courtyard of the Arousi house ...

.Photo by Lekegian ..1879

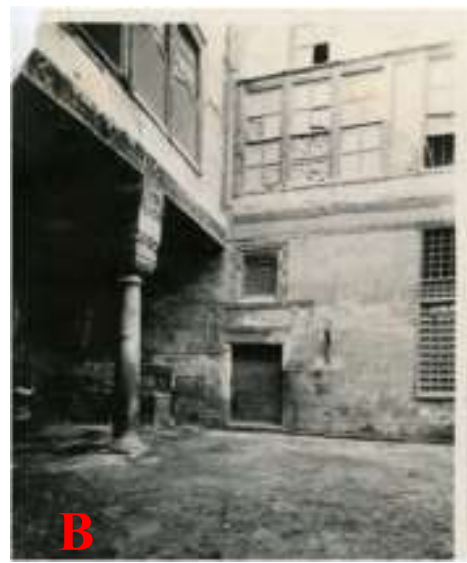

The courtyard of the Arousi house ... Photo by Hassan Abdel Wahab ...1931 


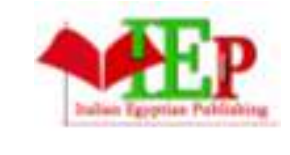

ISSN: 2785-9622
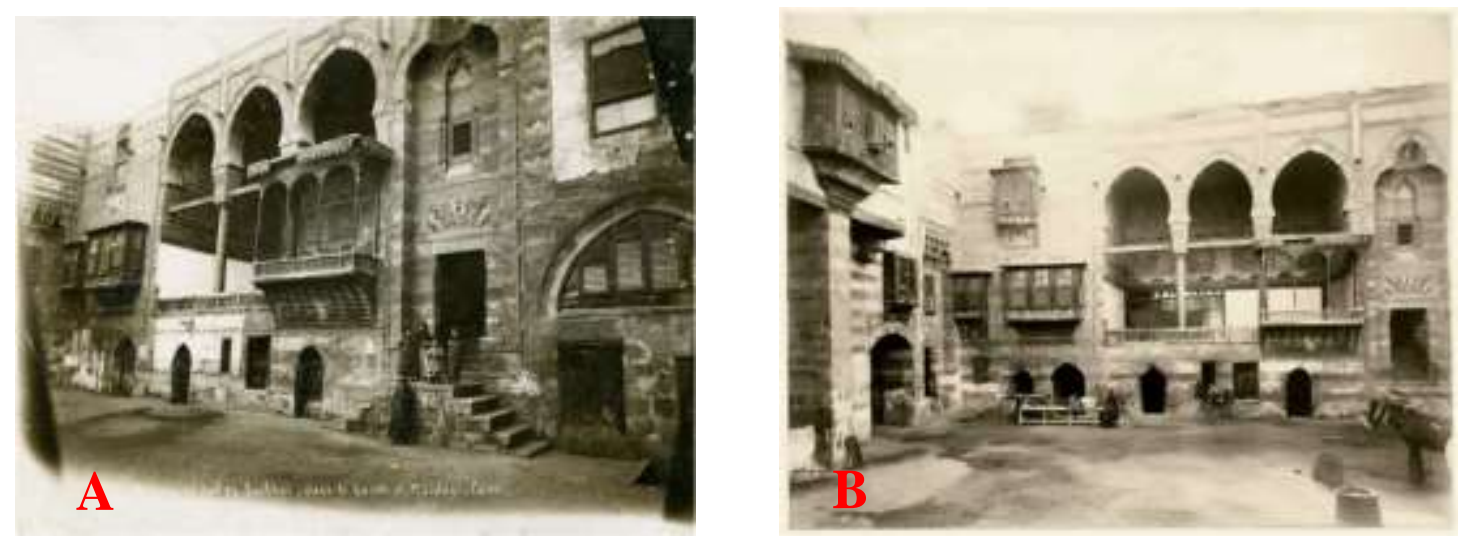

(Figure9,A.B) Huge house built by the Mamluk Sultan Al-Ashraf Abu Al-Nasr Qaitbay in the year 89 (AD 1485). It is currently located in Sikkat Al-Mardani in Al-Bab Al-Wazir district in the Al-Darb Al-Ahmar, shows difference in the elements. (Privet collection )

\section{Shafik \& Farid Zaklma archive}

Shafik Zaklma and his brother Farid, originally from Minya, They were amateur photographers and were active between 1910 - 1950. No information available about them, except the archive of photographs(mostly negatives) and few descriptions written on the negative boxes.

Perhaps one of them, Shafik, owned large farmland, Farid has a relationship with the Ministry of Agriculture, ... their books and photographic archives were sold in the nineties purchaserd from the old book dealers in Azbakeya and Abu el reesh.

they photographed many Coptic scenes from the monasteries ,from some mosques, and some of the places in Old Cairo , most of which are not published yet.

We take examples of models of mosques and churches, some of which have been subject to restoration, somewhat altered in the general form, changed the features of the place. 
Many changes occurred in those buildings during the last 50 years.especially the buildings related to religious matters are predominantly symbolic and moral in addition to the historical, archaeological and artistic importance.

Therefore, the importance of the image is to restore the visual and urban image to preserve the character and the general shape to preserve the elements of the architectural composition and preserve it for future generations.

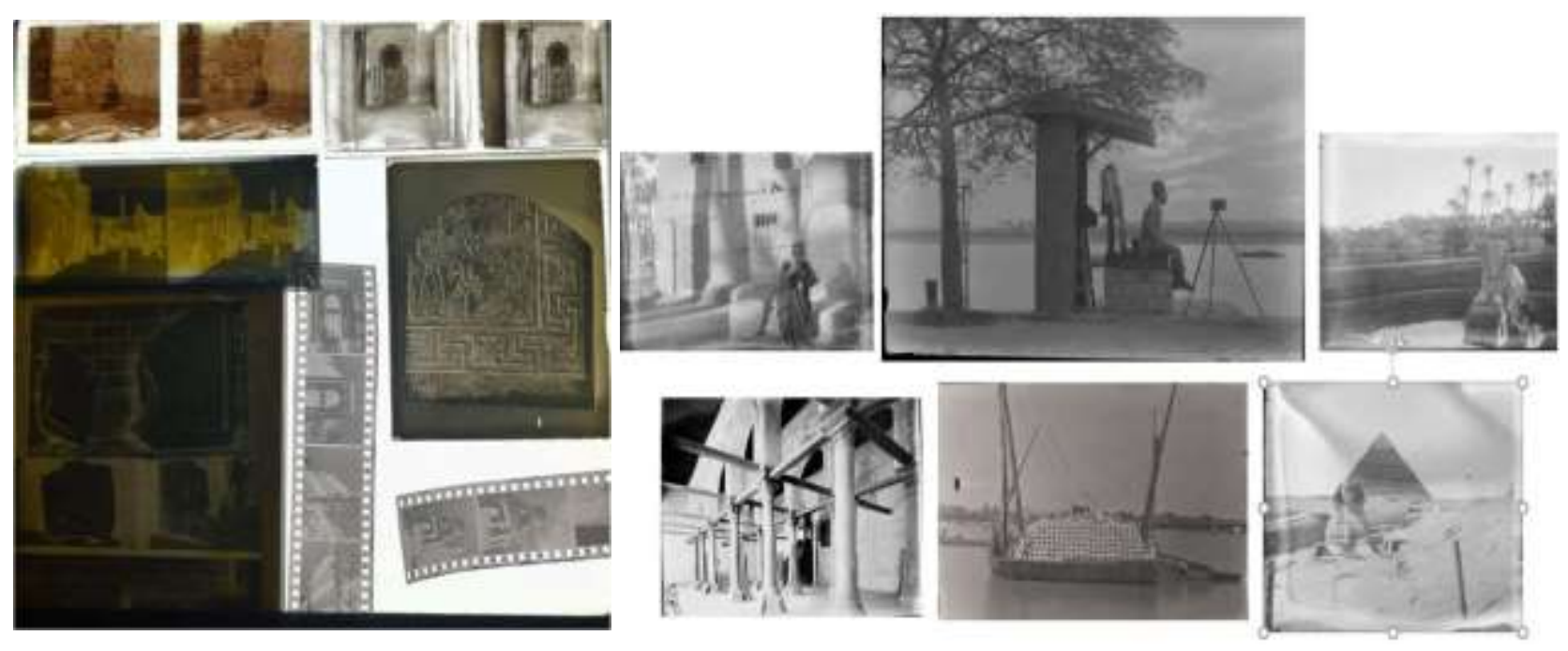

(Figure 10 )varia from zaklama archive 


\section{Saints Sergius and Bacchus Church}

Church of Martyrs Sergius and Bacchus in The Cave also known as Abu Serga,in old Cairo,the Saints were soldier- martyred during the 4th century in Syria by the Roman Emperor Maximian, is one of the oldest Coptic churches in Egypt[9]

The church was built upon an ancient Roman fort in Old Cairo called Babylon fort.[11][12]

The Church was built in the 4th century and was probably finished during the 5 th century, It was burned during the fire of Fustat under the reign of Marwan II around 750 a.C.. Then restored during the 8th century, and has been rebuilt , restored constantly since medieval times; however, it is still considered to be a model of the early Coptic churches. [25]

At the end of the Umayyad dynasty, the church was exposed to a fire (750 AD - 744), so it was restored by the Minister Youhanna bin Youssef, known as Ibn al-Abha, the keeper of the secret of the Caliph al-Muntasir Billah the Fatimid in the year 789 for the martyrs 1073 AD. [25]

Pastor Anthony mentioned in an article, that the Grotto of Christ is the holiest place in the Christian world, and it is not only a cave, but the oldest church as it was built in the year 58 AD. [26]

The importance of this church prompted the Pope of the Vatican Francis to invite Christians around the world to make a pilgrimage to the " - Abu Serga" church, just like Jerusalem, and the Church of the Holy Sepulcher.[12]

The church has been restored several times in different eras, it caused many changes in many parts of the building and it's elements, and this was proven by the pictures taken at the end of the nineteenth century and the pictures of Zaqlama, which were taken in the first quarter of the twentieth century and here compared with modern photographs in the twenty-first century. 


\section{INTERNATIONAL JOURNAL OF \\ MULTIDISCIPLINARY STUDIES IN HERITAGE \\ RESEARCH}

VOLUME 4, ISSUE 1, 2021, 260 - 283.

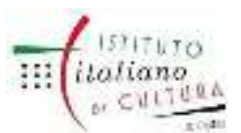

www.egyptfuture.org/ojs/

Saints Sergius and Bacchus Church (Abu Serga) Comparison of the present state with earlier photographs shows the drastic changes made to the structure

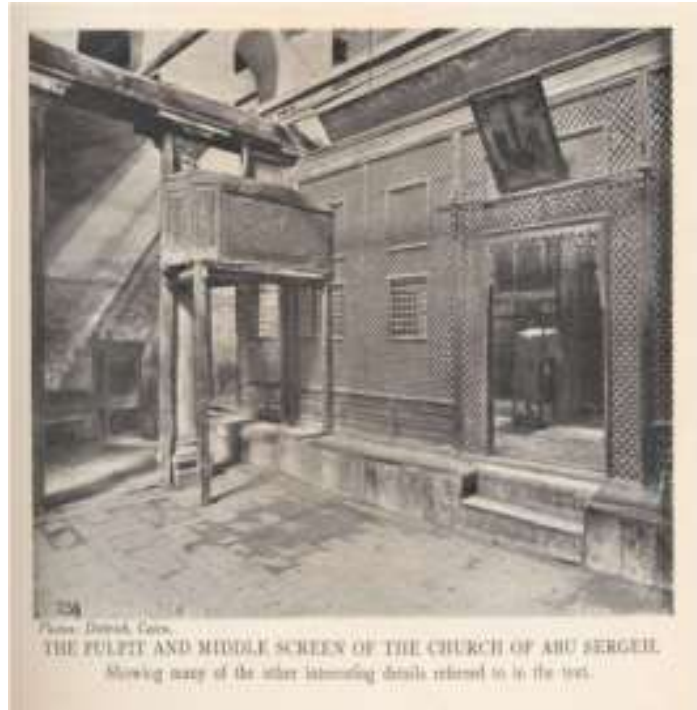

( Figure 11) The Church of Saints Sergius and Bacchus (Abu Serga). A dividing screen and other details of the interior of the church. Black- and- white photograph. Dated 1918.[14]

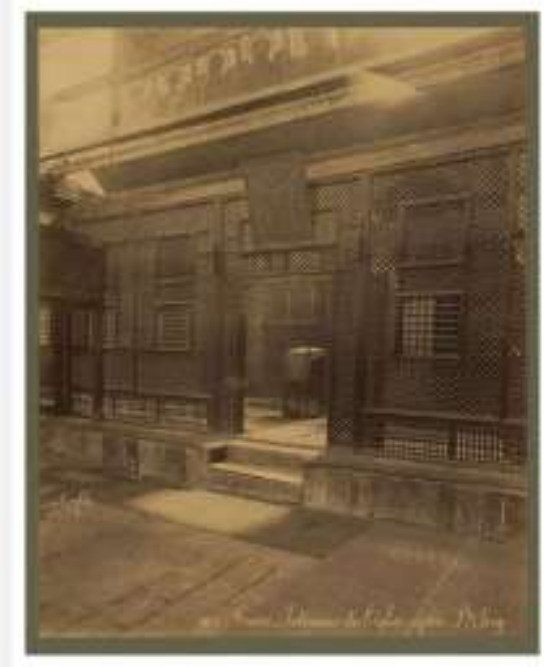

Interior of the Coptic church of Abu Serja (Saint Sergius) in Old (Coptic) Cairo

(Figure 12) Félix Bonfils Date 1886.[15] 


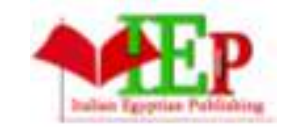

ISSN: 2785-9622

\section{INTERNATIONAL JOURNAL OF \\ MULTIDISCIPLINARY STUDIES IN HERITAGE \\ RESEARCH}

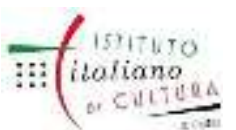

www.egyptfuture.org/ojs/

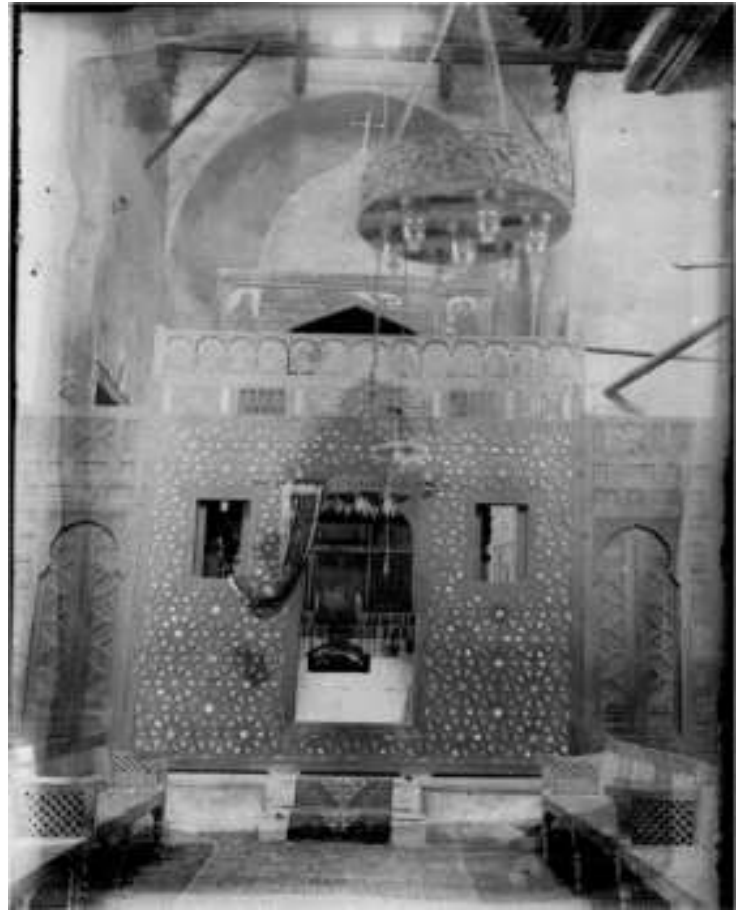

(Figure13,A.B) Interior view of Saints Sergius

Church, photo A by Zaklama .1930

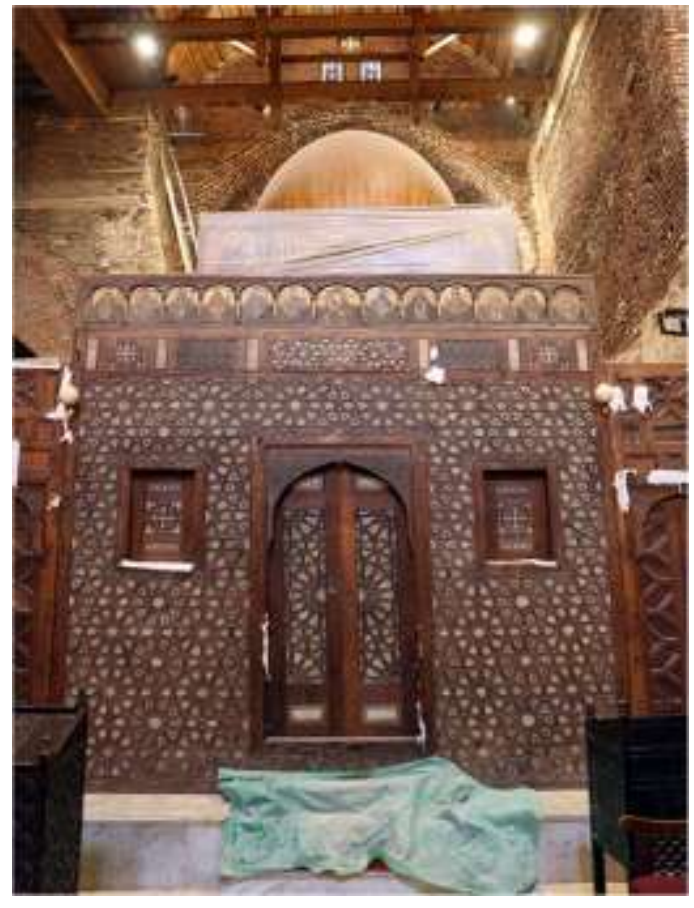

Inside the church that was built on the cavern.

Photo B, 2015.[ 16]

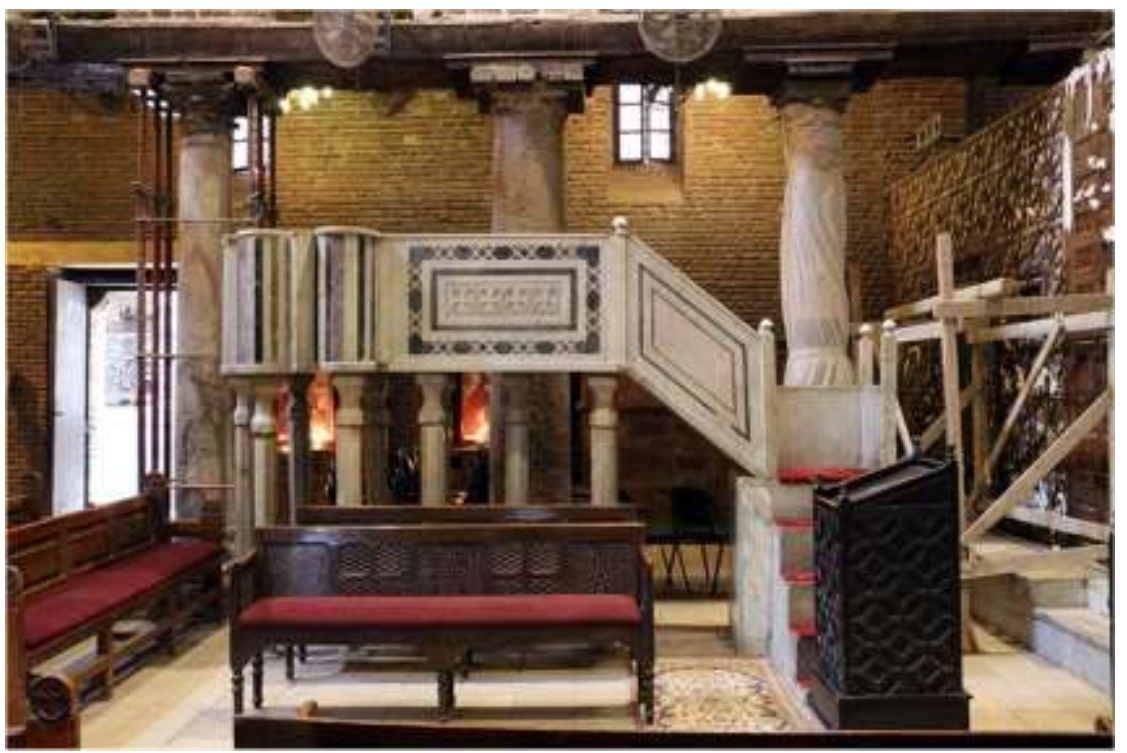

(Figure14) "Pulpit and pews in the church During the restoration and renovation.[17]

(wikimedia 2015 taken by Salico )

(Noble or anbel), [13] ( Figures.11,12,14) which is the pulpit and is called in the 


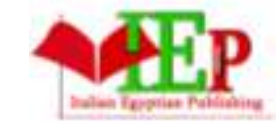

ISSN: 2785-9622
INTERNATIONAL JOURNAL OF

MULTIDISCIPLINARY STUDIES IN HERITAGE

RESEARCH

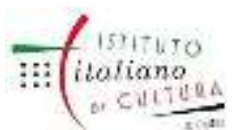

www.egyptfuture.org/ojs/

apostolic laws, and it is the elevated place that was first in the middle of the church and now on the side of the nave.[10] We found a difference that we noticed from old photos taken at the end of the 19th century and after restoration at the beginning of the 21 st century

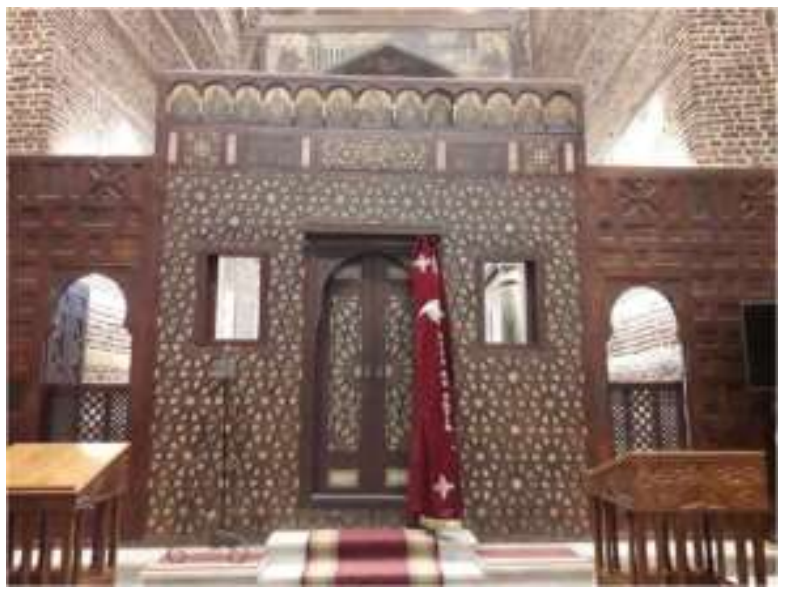

(Figure15 ) The altar area"

Photo by authors, 2021

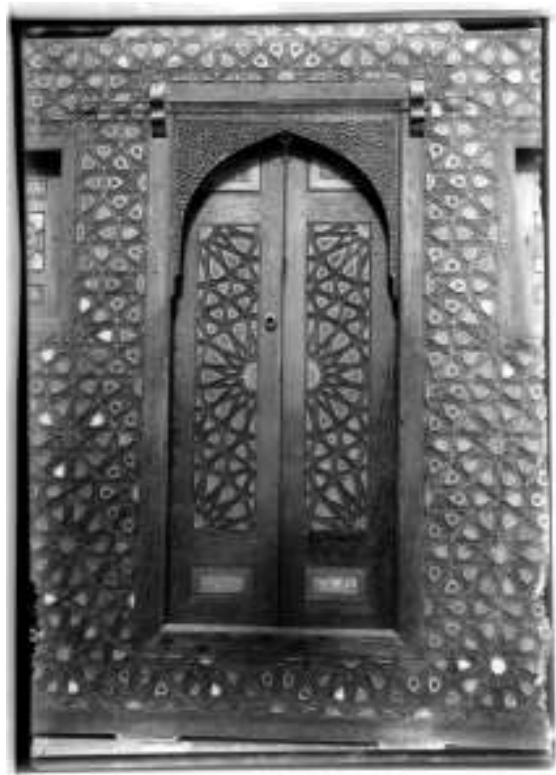

(Fiuger 16) photo by Zaklama 1930

the sanctuary iconostasis, dates to the 12th or 13th century. Several panels are inlaid with ivory and ebony, and covered in a wonderful relief that features arabesque designs.[18] 


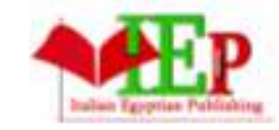

ISSN: 2785-9622

\section{INTERNATIONAL JOURNAL OF \\ MULTIDISCIPLINARY STUDIES IN HERITAGE \\ RESEARCH}

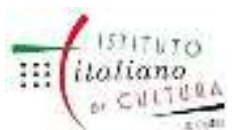

www.egyptfuture.org/ojs/

The cave where the Holy Family is said to have taken shelter after fleeing to Egypt ( Figure17,A.B.C)[10]

Inside the cave, the photographs show what was added and disappeared from the place

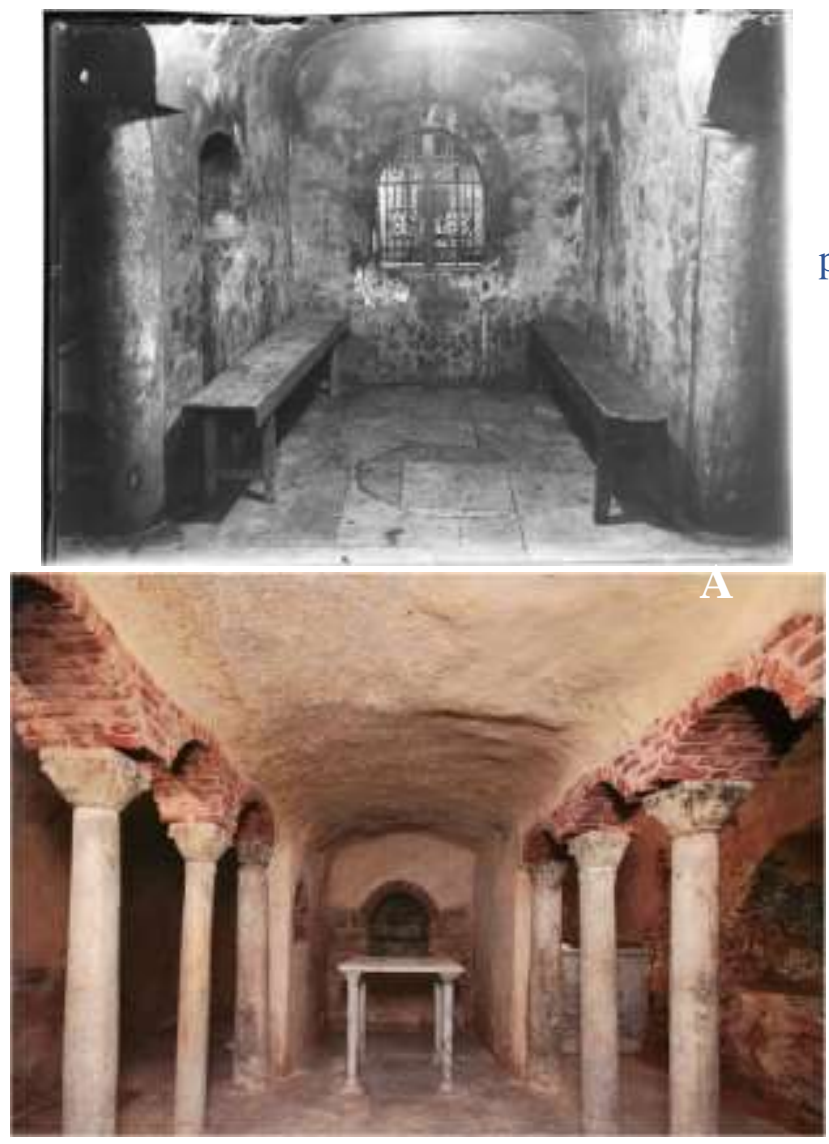

photo by Zaklama 1930

Privet collection

Dated 1991 


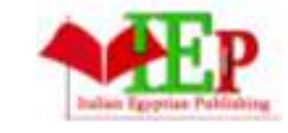

ISSN: 2785-9622

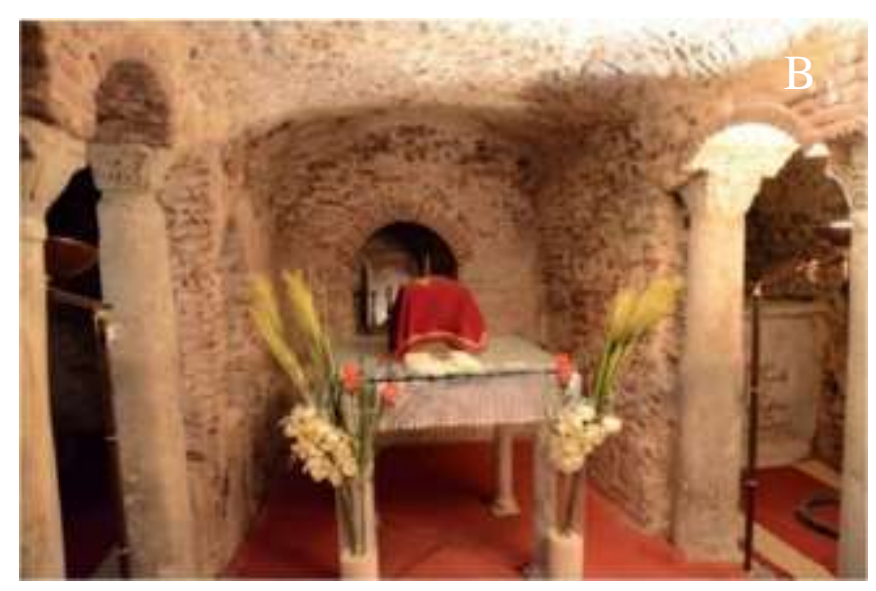

\section{6. [16]}

(Figure17, A.B.C) shows the difference in the cave before and after the restoration

\section{Mosque of Ibn Tulun at Cairo}

The mosque of ibn Tulun is the third mosque to be built in Egypt ,. It was built by Al -'Abbas Ahmed ibn Tulun in 263-265 AH/ 876-879AD. ,the oldest mosque in Egypt as well as the whole of Africa surviving in its full original form, and the largest mosque in Cairo in terms of land area.[20] Ibn Tulun Mosque contains large open space, it boasts both sunlight and shadows. It is built around an open square courtyard which allows natural light to infiltrate through. Ibn Tulun minaret features Samarra mosque style - its decorations being created from carved stucco and wood. In the middle of the courtyard is an ablutions fountain,[21] an innovation of the Mamluk sultan, Hosam al-Din Lajin (r. AH 696-8 / AD 1297-9) in AH 696 / AD 1296 . [22] This mosque is a popular tourist attraction, The mosque has been restored several times, that no major architectural changes happened to the building.[22]

It' is shown by the photographs taken to document it, Two shots separated by a hundred years(Figures 18A.b ,19A.B, 20A.B) 


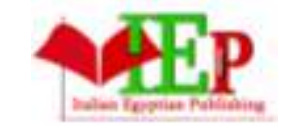

ISSN: 2785-9622

\section{INTERNATIONAL JOURNAL OF MULTIDISCIPLINARY STUDIES IN HERITAGE RESEARCH}

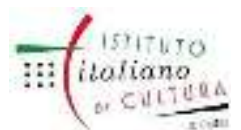

www.egyptfuture.org/ojs/

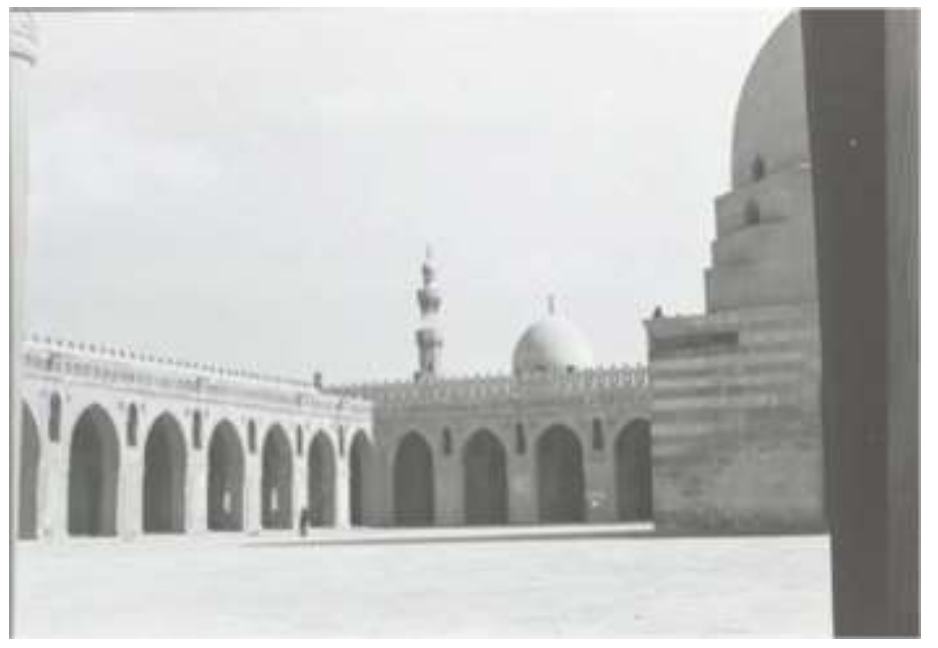

photo by authors

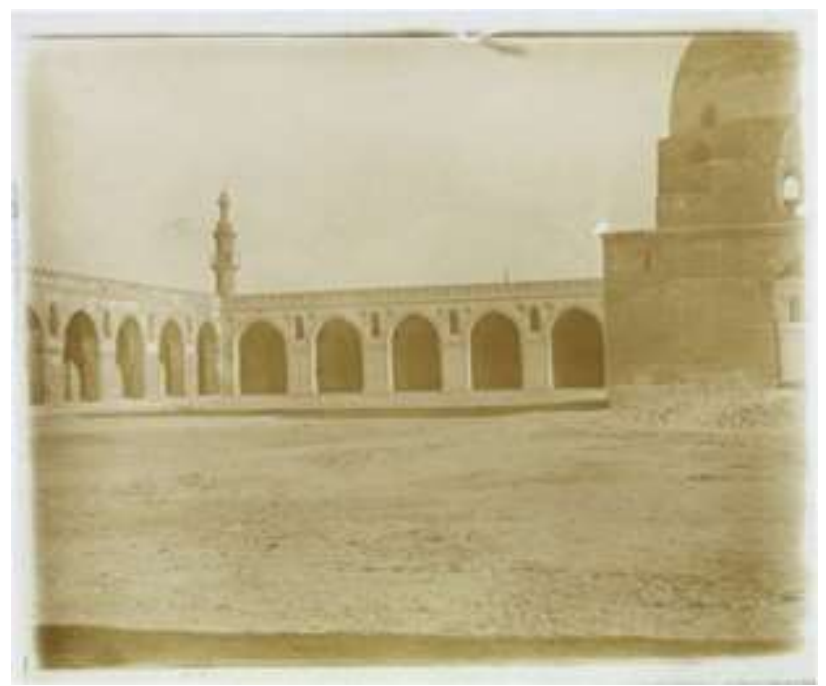

photo by Zaklama 1920

Figure 18, A.B Shows the interior shot through the courtyard

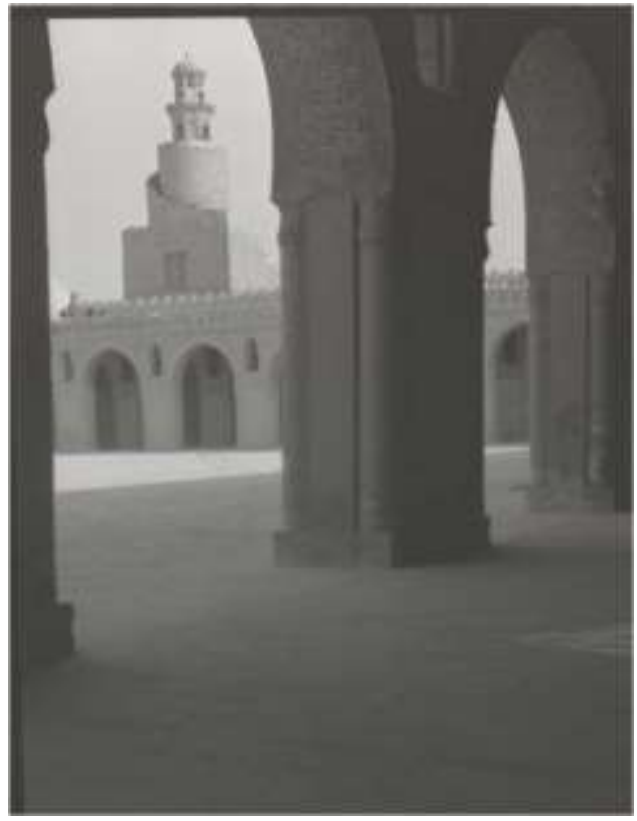

photo by authors 2021

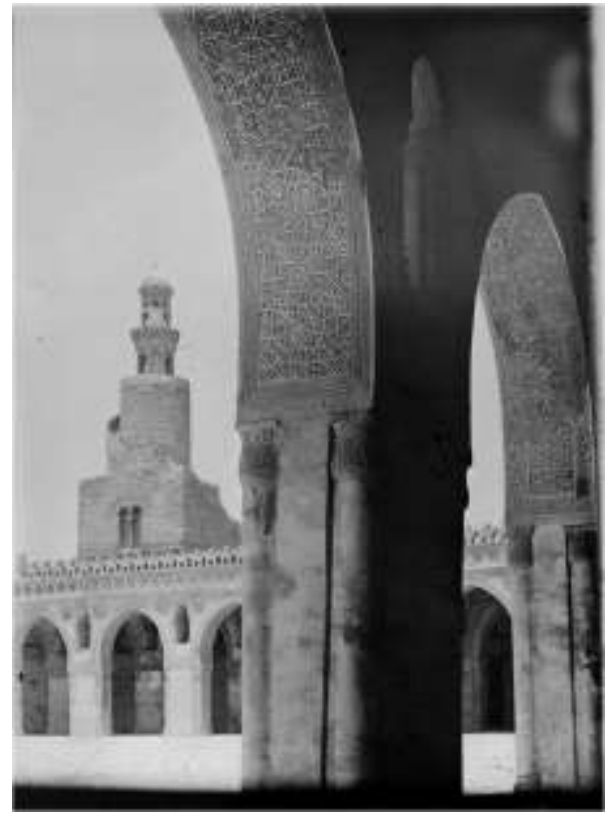

photo by Zaklama 1920 


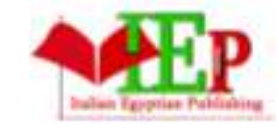

ISSN: 2785-9622
INTERNATIONAL JOURNAL OF

MULTIDISCIPLINARY STUDIES IN HERITAGE

RESEARCH

VOLUME 4, ISSUE 1, 2021, 260 - 283.

www.egyptfuture.org/ojs/

Figur 19 A.B Shows the Geometric arch decorations - The floral representations and geometric designs on the arches reflects Abbasid art.[20]

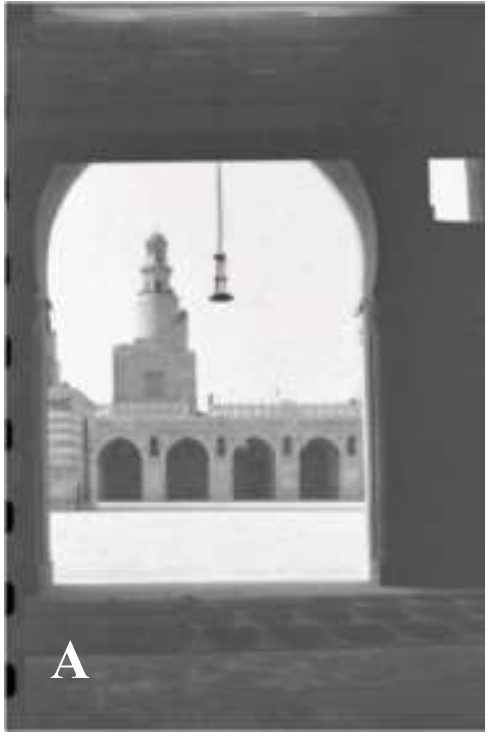

photo by authors 2021

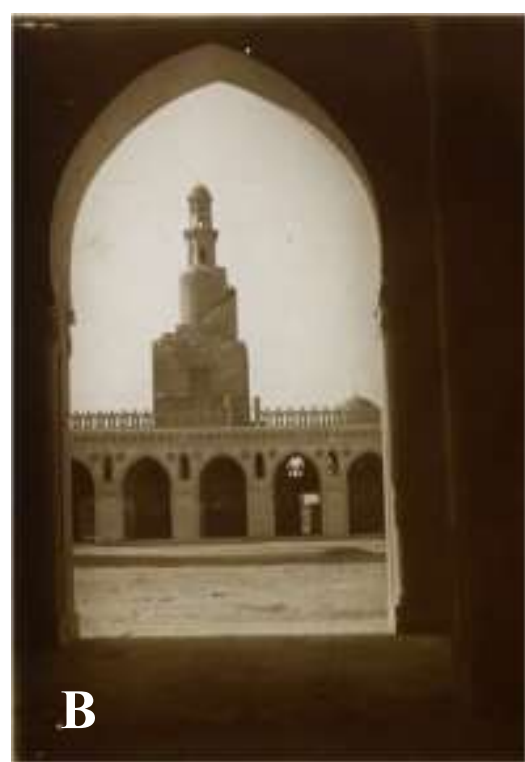

photo by Zaklama1920

( Figure 20 A.B.)The spiral minaret: It is modeled after the minarets of Samarra, with is formed of a spiral staircase around the outside.[21] 


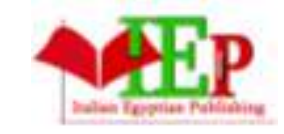

ISSN: $2785-9622$
INTERNATIONAL JOURNAL OF

MULTIDISCIPLINARY STUDIES IN HERITAGE

RESEARCH

VOLUME 4, ISSUE 1, 2021, 260-283.

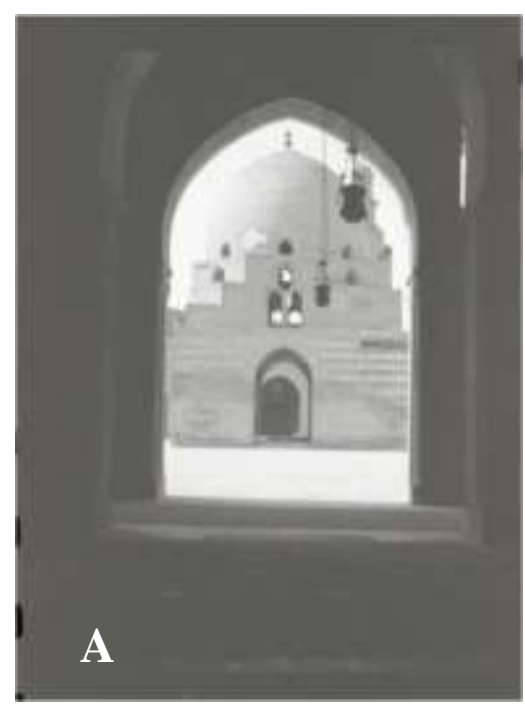

photo by authors 2021

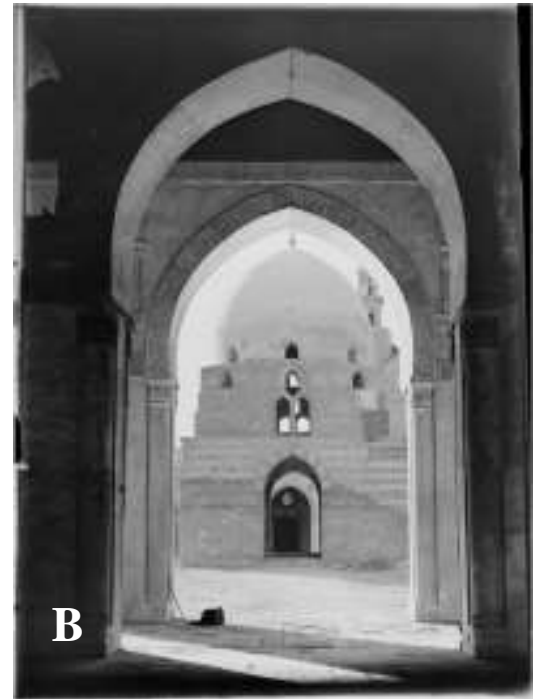

photo by Zaklama1920

Figure 21 A.B. The ablutions fountain is the work of Lajin in 1298; viewed from the the mainprayer hall

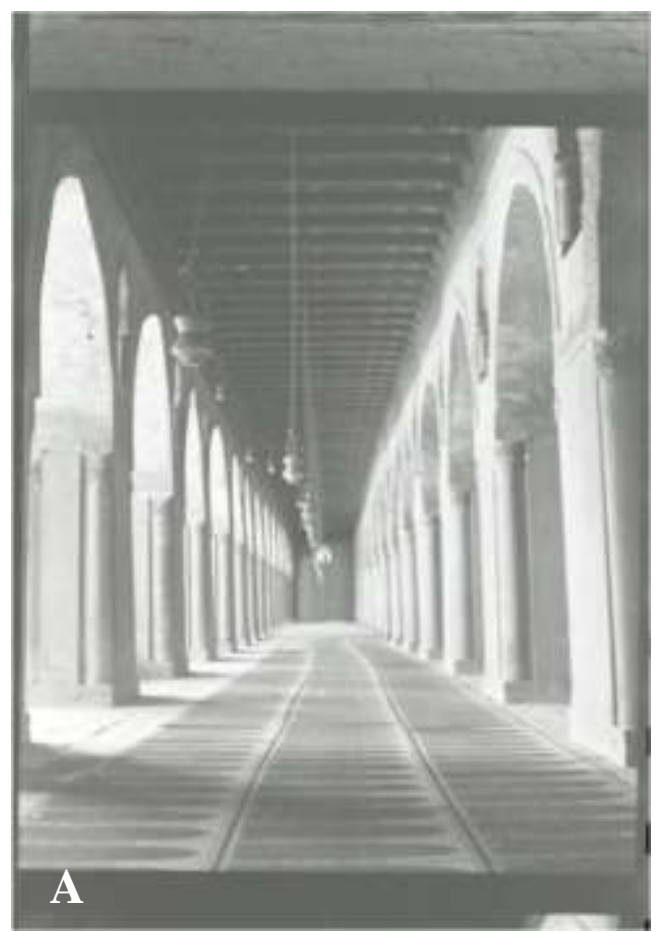

photo by authors 2021

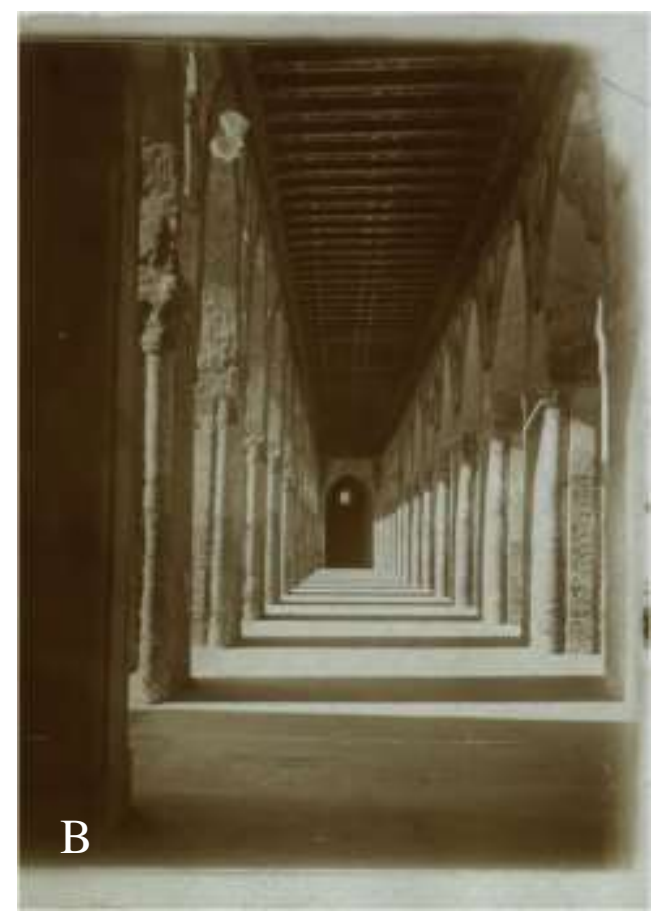

photo by Zaklama1920

Figure 22,A.B. View of an interior arcade in a riwaq showing The partially damage tostucco soffits And after its restoration 


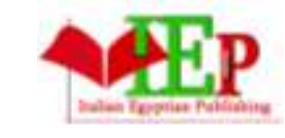

ISSN: 2785-9622

Lajin's minbar is monumental and it is an iconic piece of art (Figure 23,A.B)

The architectural elements inside the mosque contains a prayer niche (mihrab) and a wooden minbar. The hood of the mihrab has the date of the completed construction inscripted in Kufic script.[22]

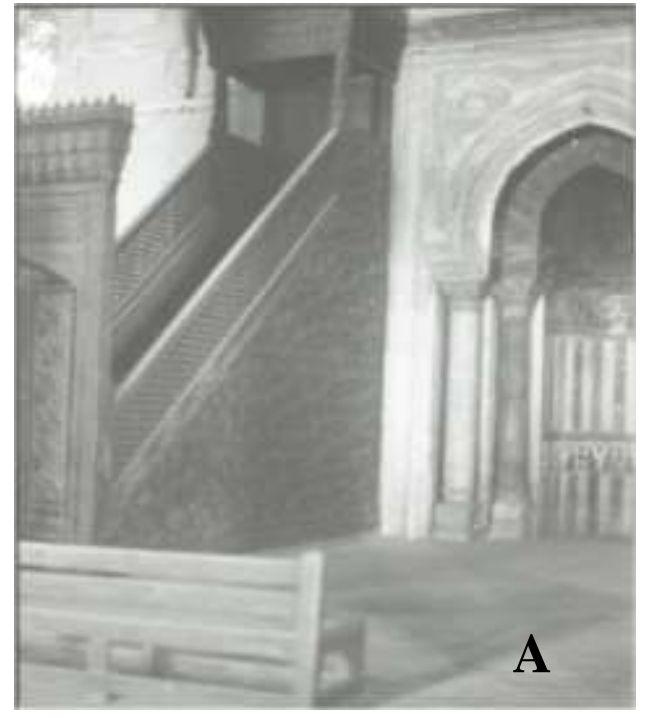

Figure 23,A .B photo by authors 2021

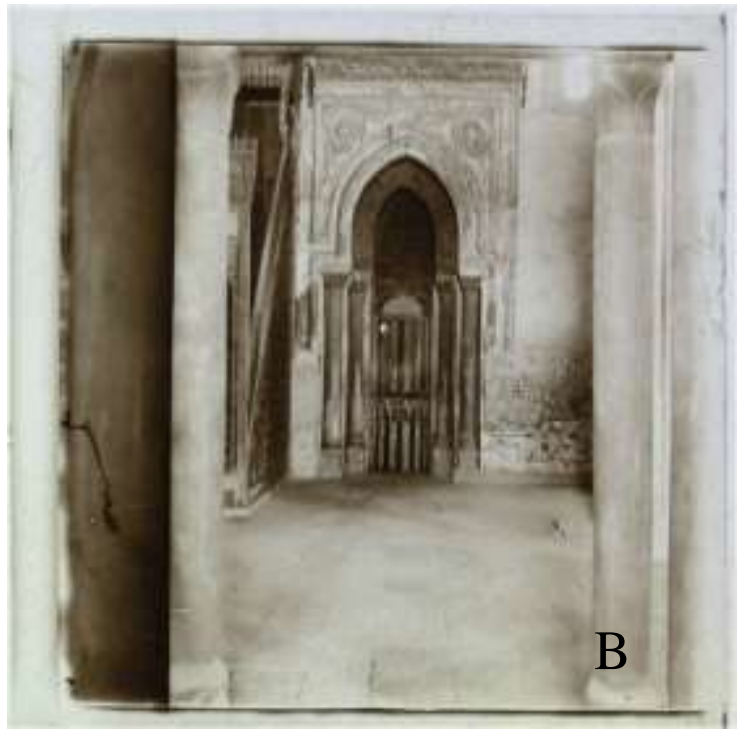

Main prayer niche. photo by Zaklama1920

All the photographs taken in the 19th century show the minbar empty without panels . Many panels traveled to Paris and were exhibited in Egypt's pavilion during the International Exhibition of1867. The majority were acquired by the Victoria and Albert Museum in London and some were bought by the Museum of Applied Art in Vienna (MAK).[24] all the panels, are not original and they are the result of a reproduction made when the minbar was restored in 1913-14 during the reign of Khedive Abbas Hilmi II. When Herz Pasha, the head of the Comite d'art arabe identified the panels in the Museum of Applied Art in ViennaMAK and requested high resolution images to be made .[24] 


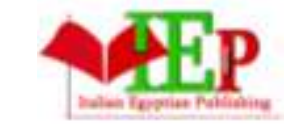

ISSN: $2785-9622$

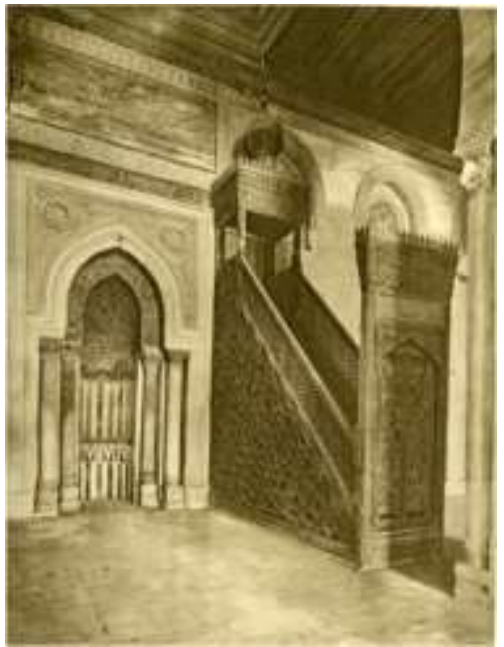

shows the minbar after restoration , 1946 [23]

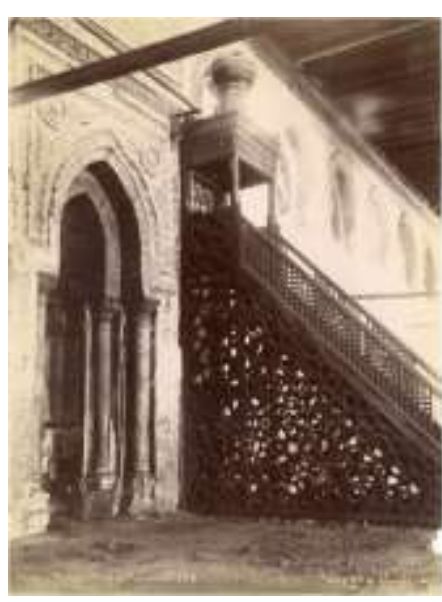

Photo albumin by G.Lekegian , 1890 circa , shows the minbar empty without panels (privet collection)

Figure 24,A.B) shows the minbar before and after restoration.

\section{Conclusion}

it is important to preserve historic cities and heritage buildings and revive them through old photographic prints. We should treat the archival photographs as precious historical documents.

photographs of cultural heritage are a necessary part of long term preservation of cultural heritage, as the physical conditions of monuments change over time, Photographs serves as a way to document and represent heritage in the begone days. 


\section{INTERNATIONAL JOURNAL OF MULTIDISCIPLINARY STUDIES IN HERITAGE RESEARCH}

\section{References}

1- Maher Hassan. (10 October, 2008). Al-Azbekiya and its theaters (1-2) Azbakeya Park.. Khedivei Park in the Mamluk style]. Al-Masry Al-Youm http://www.coptichistory.org/new_page_3649.htm

2- Lallemand, C. (1894). Le Caire. Gervais-Courtellemont.

3- Volait, M. (2012). Maisons de France au Caire: le remploi de grands décors mamelouks et ottomans dans une architecture moderne. Institut français d'archéologie orientale.

4- Peter F. Dorman, John Coleman Darnell, and Susan Lezon . The Epigraphic Survey, Oriental Institute. Lost Egypt: Photography and the Early Documentation of Egyptian Monuments.

https://oi.uchicago.edu/sites/oi.uchicago.edu/files/uploads/shared/docs/lost1.pdf

5- https://commons.wikimedia.org/wiki/File:Erment_(Hermonthis),_Vue_G\%C3\%

A9n\%C3\%A9rale_des_Ruines_-Temple_et_Mammisi_MET_DP71387.jpg

6- https://en.wikipedia.org/wiki/Shepheard\%27s_Hotel

7- Sabour, E. M. A., \& Luoni, S. (2013). Khedivial Cairo: An Evolved Metabolism. Journal of Civil Engineering and Architecture, 7(5), 616.

8- https://en.wikipedia.org/wiki/Saints_Sergius_and_Bacchus_Church_(Abu_Serga 2

9- https://egymonuments.gov.eg/monuments/church-of-saint-sergius-and-bacchus/

10- Bestawros, G. G. (2021, march). coptic-culture- old Cairo - churches- Abu

Sarga. Retrieved from coptic-cairo.com: http://www.coptic

cairo.com/oldcairo/church/sarga/sarga.html

11- https://egymonuments.gov.eg/monuments/church-of-saint-sergius-and-bacchus/

12-https://m.akhbarelyom.com/news/newdetails/

13-https://cguaa.journals.ekb.eg/article_37100_e9f5104e21371d02294851f71efa466 c.pdf

14-https://commons.wikimedia.org/wiki/File:The_Pulpit_and_Middle-

Screen_of_the_Church_of_Abu_Sergeh._(1918)_-_TIMEA.jpg

15- https://www.loc.gov/photos/?fa=location $\% 3$ Acairo $\% 7$ Clanguage $\% 3$ Afrench $\% 7$

Cpartof\%3Acoptic+churches\&st=slideshow

16-https://ar.m.wikipedia.org/wiki/\%D9\%85\%D9\%84\%D9\%81:Cairo,_chiesa_di_s an_sergio_02.JPG

17-https://upload.wikimedia.org/wikipedia/commons/e/e0/Cairo\%2C_chiesa_di_san _sergio\%2C_pulpito.JPG

18- Dunn, J. (2011, June 16th). Cairo Churches: The Church of Saints Sergius and Bacchus (Abu Serga). Retrieved from Tour Egypt :

http://www.touregypt.net/featurestories/serga.htm 


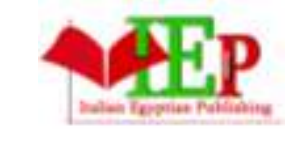

ISSN: 2785-9622

\section{INTERNATIONAL JOURNAL OF \\ MULTIDISCIPLINARY STUDIES IN HERITAGE \\ RESEARCH}

VOLUME 4, ISSUE 1, 2021, 260-283.

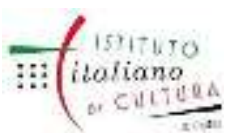

www.egyptfuture.org/ojs/

19- https://www.wataninet.com/2016/07/\%D9\%83\%D9\%86\%D9\%8A\%D8\%B3\%D $8 \%$ A9-\%D8\%A3\%D8\%A8\%D9\%88-

$\% \mathrm{D} 8 \% \mathrm{~B} 3 \% \mathrm{D} 8 \% \mathrm{~B} 1 \% \mathrm{D} 8 \% \mathrm{AC} \% \mathrm{D} 9 \% 87 / 78349 /$ article 2016

20-https://en.wikipedia.org/wiki/Mosque_of_Ibn_Tulun

21- Mahdy, H. M. (1992). Attitudes towards architectural conservation: the case of Cairo. University of Glasgow (United Kingdom) https://core.ac.uk/download/pdf/293062253.pdf

22- $\quad$ Tarek Torky "Mosque of Ahmad Ibn Tulun" in Discover Islamic Art, Museum With No Frontiers, 2021. http://islamicart.museumwnf.org/database_item.php?id=monument;ISL;eg;Mon0 $\underline{1 ; 2 ; \mathrm{ar}}$

23- Egypt. Ministry of Wakfs. \& Egypt. Survey of Egypt. (1949). The mosques of Egypt from 21 H. (641) to 1365 H. (1946) : being a series of views in colour and monochrome of the principal mosques of Egypt with a brief note on each monument describing its history and architectural features, accompanied by detailed plans and maps. Giza : Reproduced and printed by the Survey of Egypt

$$
\text { دار الكنب المصربّة. }
$$

\footnotetext{
25 https://awtar-alsama.com/wp- . ktab INC.بل content/uploads/2019/08/\%D9\%83\%D8\%AA\%D8\%A7\%D8\%A8\%D8\%AA\%D8\%A7\%D8\%B1\%D9\%8.pdf
}

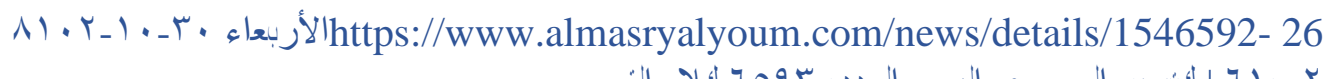

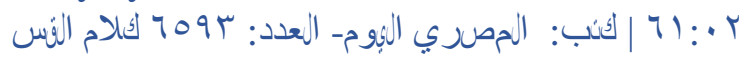

